\title{
The Effect of Lactapuncture Massage on Breast Milk Production through Prolactin Hormone Levels Changes in Dr. M. Ashari Hospital, Pemalang, Central Java
}

\author{
Siti Patimah'), Imam Djamaluddin Mashoedi²), Suharyo Hadisaputro²) \\ ${ }^{1)}$ Applied Midwifery, Graduate Program, School of Health Polytechnics, \\ Ministry of Health Semarang \\ 2)School of Health Polytechnics, Ministry of Health Semarang
}

\begin{abstract}
Background: Problems that inhibit breastfeeding in the first week include less breast milk production. Increasing breast milk production can be done by stimulating or massage the breast. Breast massage can be done by lactapuncture massage. This study aimed to examine the effect of lactapuncture massage on prolactin hormone levels and breast milk production among primiparous mothers.

Subjects and Method: This was a quasy experiment study conducted at Dr. M. Ashari hospital, Pemalang, Central Java, Indonesia. A sample of 32 primiparous postpartum mothers was selected by simple random sampling. The dependent variable was breast milk production. The independent variables were lactapuncture massage for 7 consecutive days. The data were analyzed by t-test.

Results: Prolactin hormone level in intervention group (mean $=313.80 ; \mathrm{SD}=45.54)$ was higher than in control group (mean $=292.09$; $S D=97.87)$ but it was statistically non-significant $(p=$ 0.428 ). Breast milk production in intervention group was higher (mean $=9.36 ; \mathrm{SD}=0.71$ ) than in control group (mean $=7.39 ; \mathrm{SD}=0.23$ ) and it was statistically significant $(\mathrm{p}<0.001)$.

Conclusion: The lactapuncture massage on 2-3 times clockwise at each point for 7 consecutive days increasing prolactin hormone levels and on breast milk production.
\end{abstract}

Keywords: lactapuncture massage, prolactin hormone, breast milk production

\section{Correspondence:}

Siti Patimah. Applied Midwifery, Graduate Program, School of Health Polytechnics, Ministry of Health Semarang. Email: imafatimah922@gmail.com. Mobile: o81329283952

\section{BACKGROUND}

One method to increase breast milk production mothers is lactapunktur massage. Lactapunktur massage is one method that is still rarely used to stimulate the productivity of breast milk. The Lactapunktur technique can be applied as complementary therapy in postpartum mothers. These therapies help smooth the flow of energy, blood circulation, lymph flow and nervous system so that it can affect the workings of hormone metabolism. This therapy can be done as an effort to increase the hormone prolactin in the breastfeeding process (Kemenkes RI Direktorat Bina Pelayanan
Kesehatan Tradisional, Alternatif dan Komplementer, 2012; Widiastuti et al., 2015).

Lactapunktur is development of acupuncture techniques. Laktapunktur is branch of science from traditional Chinese acupuncture medicine, but is more focused on the breast. The lactanture technique suppresses the acupuncture point using finger to stimulate response in the body (Wong, 2010). Lactapunktur does not use pills, stimulants or needles so that it is safe for mothers and even infants. Lactapuncular therapy can also be done using a massage aid in the form of a blunt object and supporting materials such as cream, lotion or massage oil (Kemenkes RI Direk- 
torat Bina Pelayanan Kesehatan Tradisional, Alternatif dan Komplementer, 2012).

The lactanture technique combines acupuncture and suggestive. The concept of lactapunktur technique is that mother who is breastfeeding is not only seen or assisted by physical aspects but the process of psychological adaptation is also a study (Kemenkes RI Direktorat Bina Pelayanan Kesehatan Tradisional, Alternatif dan Komplementer, 2012; Widiastuti, Arifah, \& Rahmawati, 2015). His study conducted in China explained that acupressure massage can eliminate meridian blockages so that it can reduce the scale of breast pain in postpartum mothers with engorgement. Smooth flow of meridians and a decrease in engorgement are expected to help mothers in the breastfeeding process (Chen, 2011). Massage techniques can increase breast milk production (Mardiyaningsih, 2011; Hamidah, 2016; Neri et al., 2011; Pamuji et al., 2014). Massage techniques can also increase levels of hormone prolactin (Pamuji et al., 2014; Raras, 2016; Fitriani, 2015). The lactapuncular massage study can change the production of breast milk through changes in hormone levels of prolactin as long as the researchers' knowledge has not been studied by other researchers.

Based on the description above, the aim of this study is to prove the effect of lactapuncture massage on breast milk production of primiparous mothers through changes in the levels of the hormone prolactin. The specific objective of this study is to find out the effect of lactanture massage as much as 2-3 times clockwise at each point for 7 consecutive days increasing the levels of prolactin hormone in primiparous mothers and breast milk production of primiparous mothers.

\section{SUBJECTS AND METHOD}

\section{Study Design}

This study used type of quasy experiment research with the design of the pretest and posttest with control group design. In this study, it was divided into 2 groups, namely the control group and the intervention group which was given treatment that is lactapuncholic massage.

\section{Population and Sample}

Sample are primiparous mothers on the first day at Dr. M. Ashari Pemalang District Hospital in the 2nd week of July to the first week of August 2018. A sample of 32 lactating mothers was selected by simple random sampling.

\section{Study Variables}

The independent variable is lactapuncture massage for 7 consecutive days, the intermediate variable is hormone prolactin level, and the dependent variable is breast milk production.

\section{Study Instrument}

The study instrument included questionnaire, checklist, microplate reader, and observation sheet.

\section{Data Analysis}

Data analysis methods in this study were univariate analysis, normality test, homogeneity test, and bivariate analysis.

\section{Research Ethics}

This study has obtained research ethics letter from the Ethics of the Islamic University of Sultan Agung (Unissula) Semarang number: 270/VII/2018/Komisi Etik date July 31, 2018.

\begin{tabular}{l}
\hline RESULTS \\
\hline 1. Univariate Analysis \\
Gestational age in intervention group \\
(mean= 38.81; $\mathrm{SD}=1.17)$ almost as equal as \\
in control group (mean $=38.5 ; \mathrm{SD}=1.16)$. \\
There were no differences of gestational age \\
between intervention and control groups \\
$(\mathrm{p}=$ 0.086). Infants birth weight in inter-
\end{tabular}


vention group was higher (mean $=3,600$; 3406.25; $\mathrm{SD}=321.39)$

$\mathrm{SD}=292.12$ ) than in control group (mean=

Table 1. Sample characteristics by gestational age and infant birth weight

\begin{tabular}{lccc}
\hline \multirow{2}{*}{ Variable } & \multicolumn{2}{c}{ Groups } & \multirow{2}{*}{ p } \\
\cline { 2 - 3 } Gestational age & Intervention $(\mathbf{n}=\mathbf{1 6})$ & Control $(\mathbf{n}=\mathbf{1 6})$ & \\
Mean \pm SD & $38.5 \pm 1.16$ & $38.81 \pm 1.17$ & \multirow{2}{*}{0.468} \\
Median & 38.5 & 39.0 & \\
Min \pm Max & $37 \pm 408$ & $37 \pm 40$ & \\
Infant Birth Weight & & & \\
Mean \pm SD & $3406.25 \pm 321.90$ & $3600 \pm 292.12$ & 0.086 \\
Median & 3400 & 3700 & \\
Min \pm Max & $2900 \pm 3900$ & $3000 \pm 3900$ & \\
\hline
\end{tabular}

2. Bivariate Analysis

a. Prolactin Hormone Level

After being given lactapuncture massage intervention for 7 consecutive days, prolactin hormone level in intervention group

Table 2. The effect of 7 consecutive days of lactapuncture massage on changes in prolactin hormone levels in primiparous mothers

\begin{tabular}{lccc}
\hline \multicolumn{1}{c}{ Prolactin Hormone Level } & Mean & SD & p \\
\hline Pre & & & \\
Intervention & 254.13 & 60.14 & 0.420 \\
Control & 275.36 & 84.55 & \\
Post & & & \\
Intervention & 313.80 & 45.54 & 0.428 \\
Control & 292.09 & 97.87 & \\
\hline
\end{tabular}

\section{b. Breast Milk Production}

After getting lactapunture massage for 7 consecutive days, breast milk production in intervention group was higher (mean=

Table 3. The effect of lactapunctur massage for 7 consecutive days on changes in breast milk production in primiparous mother

\begin{tabular}{lccc}
\hline \multicolumn{1}{c}{ Breast Milk Production } & Mean & SD & p \\
\hline Pre & & & 0.451 \\
Intervention & 2.47 & 0.19 & \\
Control & 2.42 & 0.18 & $<0.001$ \\
Post & & & \\
Intervention & 9.36 & 0.71 & 0.23 \\
Control & 7.39 & & \\
\hline
\end{tabular}

Table 4. Mean of breast milk production for 7 consecutive days

\begin{tabular}{lcccccccc}
\hline Breast Milk & \multicolumn{8}{c}{ Days } \\
\cline { 2 - 10 } Production & $\mathbf{0}$ & $\mathbf{1}$ & $\mathbf{2}$ & $\mathbf{3}$ & $\mathbf{4}$ & $\mathbf{5}$ & $\mathbf{6}$ & $\mathbf{7}$ \\
\hline Intervention & 2.47 & 3.45 & 4.44 & 5.42 & 6.41 & 7.39 & 8.38 & 9.36 \\
Control & 2.42 & 3.13 & 3.84 & 4.55 & 5.26 & 5.97 & 6.68 & 7.39 \\
\hline
\end{tabular}


Indonesian Journal of Medicine (2019), 4(1): 15-20

https://doi.org/10.26911/theijmed.2019.04.01.03

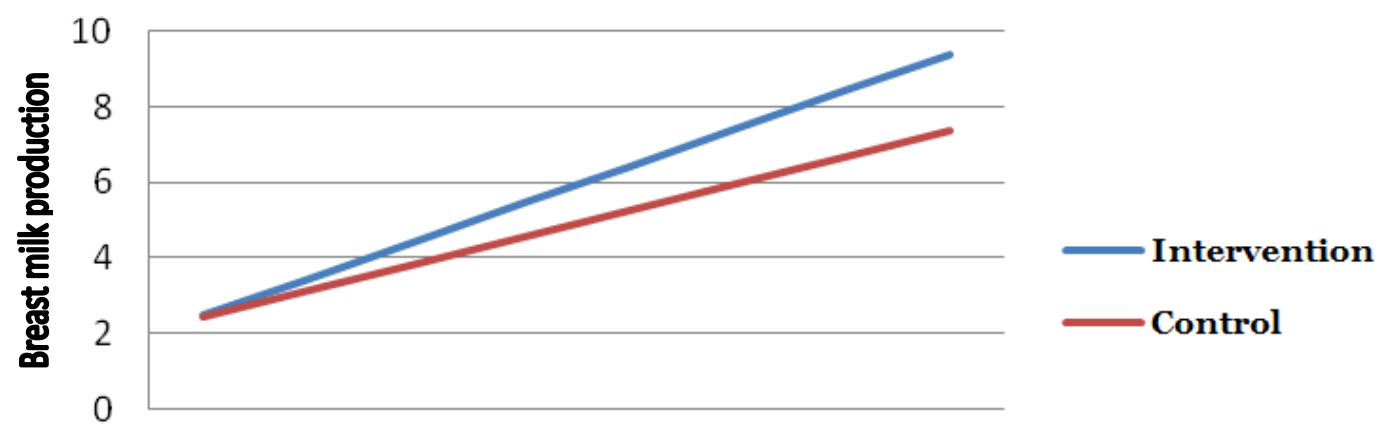

Day-o Day-1 Day-2 Day-3 Day-4 Day-5 Day-6 Day-7

Figure 1. Mean of breast milk production for 7 consecutive days among primiparous mother

\section{DISCUSSION \\ 1. Prolactin hormone level}

After being given lactapuncture massage intervention for 7 consecutive days, prolactin hormone level in intervention group was higher than in control group but it was statistically non-significant.

The results of this study were in line with Raras (2016), which stated that the combination of acupressure and aromatherapy was effective in increasing in prolactin hormone levels (Raras, 2016). The results of this study were consistent with Pamuji et al. (2014), which stated that there were differences between prolactin levels among primiparous mothers after being given a combination of woolwich massage methods with endorphin compared to the control group $(p=0.034)$. The results of this study was also in accordance with Fitriani (2015), which stated that the combination of oxytocin massage and administration of black cumin capsules was more effective in increasing prolactin hormone levels in post cesarean section mothers.

Lactapunture technique combined acupuncture and suggestive. The concept of lactapuncture technique was mother who was breastfeeding not only seen or assisted by physical aspects but the process of psychological adaptation was also done
(Minister of Health RI, Directorate of Traditional Health Services Development, Alternative and Complementer, 2012; Widiastuti et al., 2015). Normal prolactin levels of pregnant women was $10-25 \mathrm{ng} / \mathrm{mL}$ rise to $200-400 \mathrm{ng} / \mathrm{mL}$ and continued to increase sharply at the onset of breastfeeding resulting in hyper prolactinemia. Then it started to decline, but if the frequency of breastfeeding was maintained then the levels can remain above normal for 18 months or more.

\section{Breast milk production}

After getting lactapunture massage for 7 consecutive days, breast milk production in intervention group was higher than in control group and it was statistically significant.

The results of this study were in accordance with Mardiyaningsih (2011), which stated that primiparous mothers got combination of marmet technique and oxytocin massage had an opportunity by 11.5 times greater to have smoother breast milk production than the control group.

The results of this study were in accordance with Hamidah and Isnaeni (2016), which stated that there was an influence of Marmet technique on breast milk production in primiparous mothers. 
The results of this study also were in line with Neri et al. (2011), which stated that acupuncture techniques were effective in increasing breast milk production.

Pamuji et al. (2014) reported that there was a difference between the volume of breast milk in primiparous mothers after getting combination of Woolwich massage and endorphin $(\mathrm{p}<0.001)$.

A study conducted in China explained that acupressure massage can eliminate meridian blockages so that it can reduce the scale of breast pain in primipara mothers with engorgement. Smooth flow of meridians and a decrease in engorgement were expected to help mothers in the breastfeeding process (Chen, 2011). Massage technique can increase breast milk production (Mardiyaningsih, 2011; Hamidah, 2016; Neri et al., 2011; Pamuji et al., 2014). Massage can also increase prolactin hormone level (Pamuji et al., 2014; Raras, 2016; Fitriani, 2015).

Breast milk production was the volume of milk breast milk measured for 7 days using a measuring cup. The value of breast milk production was taken based on the average volume of breast milk production per day. Breastfeeding using a breast milk pump was carried out on both breasts before the mother interferes with the baby or 2-3 hours after breastfeeding (Siregar, 2004; Saryono and Pramitasari, 2009; Proverawati and Rahmawati, 2010; Maryunani, 2012; Roesli, 2009).

Lactapuncture technique can be applied as complementary therapy in primiparous mothers. These therapies helped to smooth the flow of energy, blood circulation, lymph flow and nervous system so that it can affect the workings of hormone metabolism. So that this therapy can be done as an effort to increase the hormone prolactin in the breastfeeding process (Minister of Health RI, Directorate of
Traditional, Alternative and Complementary Health Services Development, 2012; Widiastuti et al., 2015).

\section{REFERENCES}

Chen C (2011). Efficacy of acupressure on breast engorgement in postpartum mother, China: Institute of Natural.

Fitriani YD (2015). Efektifitas kombinasi pijat oksiosin dan pemberian kapsul jintan hitam terhadap kadar hormon prolaktin pada ibu postpartum dengan section sesarea di RSU Sarila Husada Sragen. 11(3).

Hamidah K (2016). Pengaruh teknik marmet terhadap produksi ASI pada ibu postpartum di rumah sakit PKU Muhammadiyah Gamping. Yogyakarta: Program Studi Bidan Pendidik Jenjang Diploma IV Fakultas Ilmu Kesehatan Universitas 'Aisyiyah Yogyakarta.

Kemenkes RI Direktorat Bina Pelayanan Kesehatan Tradisional, Alternatif dan Komplementer (2012). Modul Orientasi Akupresur Bagi Petugas Puskesmas, Jakarta: Kementerian Kesehatan RI.

Mardiyaningsih E (2011). Efektifitas kombinasi teknik marmet dan pijat Oksitosin terhadap produksi ASI ibu postpartum seksio sesarea di rumah sakit wilayah Jawa Tengah. Jurnal Keperawatan Soedirman. 6(1). http://dx.doi.org/10.20884/1.jks.2011.6.1.321

Maryunani A (2012). Inisiasi menyusu dini, ASI eksklusif dan manajemen laktasi. Jakarta: CV.Trans Info Media.

Neri I, Gianni A, Valentina V, Simona M (2011). Acupuncture treatment as breastfeeding support: Preliminary Data', J Altern Complement Med. 17(2): 133-7. doi: 10.1089/acm.2009.0714 . 
Indonesian Journal of Medicine (2019), 4(1): 15-20

https://doi.org/10.26911/theijmed.2019.04.01.03

Pamuji SEB, Supriyana, Rahayu S, Suhartono (2014). Pengaruh kombinasi metode pijat woolwich dan endorphine terhadap kadar hormon prolaktin dan volume ASI (Studi Pada Ibu Postpartum di Griya Hamil Sehat Mejasem Kabupaten Tegal). BHAMADA, JITK. 5(1): 85-96.

Proverawati A, Rahmawati E (2010). Kapita Selekta: ASI dan Menyusui, Yogyakarta: Nuha Medika.

Raras NS (2016). Different amount of prolactin hormone before and after acupressure-aromatherapy combination technique in lactation: Epidemiological-clinic study on post partum mother in Surakarta District Hospital. http://aasic.org/proc/aasic/article/view/194/191.
Roesli U (2009) Manajemen Laktasi, Jakarta: IDAI.

Saryono, Pramitasari RD (2009). Perawatan Payudara: Dilengkapi dengan deteksi dini terhadap penyakit kanker payudara, Yogyakarta: Nuha Medika.

Siregar A (2004) Pemberian ASI eksklusif dan faktor-faktor yang mempengaruhinya, Medan: FKM USU.

Widiastuti A, Arifah S, Rahmawati WR (2015). Effect of marmet technique with breast massage of three days post partum to breastfeeding smoothness and gain baby weight. Jurnal Riset Kesehatan. 4(3):826-31.

Wong M (2010). Panduan Lengkap Pijat, Jakarta: Penebar Plus 